\title{
Copper and zinc forms in soil fertilized with pig slurry in the bean crop
}

\author{
Marco A. Grohskopf ${ }^{1}$, Juliano C. Correa ${ }^{2}$, Paulo C. Cassol ${ }^{3}$, \\ Rodrigo S. Nicoloso ${ }^{2} \&$ Dirceu M. Fernandes ${ }^{1}$ \\ ${ }^{1}$ Universidade Estadual Paulista "Júlio de Mesquita Filho"/Faculdade de Ciências Agronômicas/Departamento de Solos e Recursos Ambientais. \\ Botucatu, SP. E-mail: marcogrohskopf@gmail.com (Corresponding author); dmfernandes@fca.unesp.br \\ ${ }^{2}$ Embrapa Suínos e Aves. Concórdia, SC. E-mail: juliano.correa@embrapa.br; rodrigo.nicoloso@embrapa.br \\ ${ }^{3}$ Universidade do Estado de Santa Catarina/Centro de Ciências Agroveterinárias/Departamento de Solos e Recursos Naturais. Lages, SC. E-mail: \\ paulo.cassol@udesc.br
}

\section{Key words:}

swine slurry

uptake

metals fractionation

\begin{abstract}
A B S T R A C T
The application of pig slurry may have different influence on copper $(\mathrm{Cu})$ and zinc $(\mathrm{Zn})$ dynamics in the soil compared with mineral fertilization. The aim of this research was to determine the different forms of $\mathrm{Cu}$ and $\mathrm{Zn}$ in soil and their uptake by bean plants in response to the application of mineral fertilizer and pig slurry (PS). The treatments were: mineral fertilizer ( $\mathrm{Cu}$ and $\mathrm{Zn}$ oxides) and liquid pig slurry, at increasing rates $(0 / 0,1.7 / 6.0$, $3.4 / 12.0$ and $6.8 / 24.0 \mathrm{~kg} \mathrm{ha}^{-1} \mathrm{Cu} / \mathrm{Zn}$, respectively) applied in a Rhodic Kandiudox. PS increased the $\mathrm{Cu}$ content in soil in the exchangeable form, Fe oxides and residual, while the mineral fertilizer increased $\mathrm{Cu}$ contents in the fraction associated with soil organic matter. Soil $\mathrm{Zn}$ contents in the fractions available, exchangeable and SOM were highest under mineral fertilization, while in the soluble fraction the contents were highest under PS. The fertilizers had not impact on $\mathrm{Cu}$ and $\mathrm{Zn}$ contents associated with $\mathrm{Al}$ oxides, and these elements were mostly associated with Fe oxides in the soil. PS promoted the highest biomass production in shoots and roots of the bean plants, reflecting in the highest accumulation of $\mathrm{Cu}$ and $\mathrm{Zn}$.
\end{abstract}

\section{Palavras-chave:}

esterco de suíno

absorção

fracionamento de metais

\section{Formas de cobre e zinco no solo adubado com dejeto suíno na cultura do feijão}

\begin{abstract}
R E S U M O
A aplicação de dejeto suíno pode ter influência diferente na dinâmica do cobre $(\mathrm{Cu})$ e zinco $(\mathrm{Zn})$ no solo em relação à adubação mineral. Objetivou-se, neste trabalho, determinar as formas de $\mathrm{Cu}$ e $\mathrm{Zn}$ no solo e sua absorção pelas plantas de feijão em resposta à aplicação de fertilizante mineral e dejeto suíno, cujos tratamentos foram: fertilizante mineral (óxido de $\mathrm{Cu} / \mathrm{Zn}$ ) e dejeto suíno (DS) em doses crescentes $\left(0 / 0,1,7 / 6,0,3,4 / 12,0\right.$ e 6,8/24,0 $\mathrm{kg} \mathrm{ha}^{-1}$ de $\mathrm{Cu} / \mathrm{Zn}$, respectivamente) aplicados em Nitossolo Vermelho. O DS aumentou o teor de $\mathrm{Cu}$ no solo nas frações disponível, trocável, óxidos de Fe e residual enquanto o fertilizante mineral aumentou na fração associada a matéria orgânica do solo (MOS). O teor de Zn no solo nas frações disponível, trocável e MOS foi maior na aplicação de fertilizante mineral enquanto na fração solúvel foi maior com o DS. Os fertilizantes não interferiram no teor de $\mathrm{Cu}$ nem no $\mathrm{Zn}$ ligados aos óxidos de $\mathrm{Al}$ sendo a maior parte associada aos óxidos de Fe no solo. O DS proporcionou maior produção de biomassa de parte aérea e raízes nas plantas de feijão refletindo no maior acúmulo de $\mathrm{Cu}$ e $\mathrm{Zn}$.
\end{abstract}




\section{INTRODUCTION}

Monitoring elements with pollutant potential in the agricultural production system is based on the premise that the factors plant, soil, water and agricultural practices are interdependent. The application of pig slurry (PS) in the soil without the proper technical criteria may favor the excess of metals in the soil, which include copper $(\mathrm{Cu})$ and zinc $(\mathrm{Zn})$ (Ceretta et al., 2010; Girotto et al., 2010).

The high concentration of $\mathrm{Cu}$ and $\mathrm{Zn}$ in the PS is due to the surplus used in the feed to compensate the low use by the animal, since approximately $85 \%$ of the $\mathrm{Cu}$ and $98 \%$ of the $\mathrm{Zn}$ present in the feed are excreted (Marcato, 1997). Plants absorb small amounts of these metals, while the application of PS for many years or at high doses may lead to accumulation of $\mathrm{Cu}$ and $\mathrm{Zn}$ in the soil (Mattias et al., 2010).

In order to increase the efficiency of use of this fertilizer, it is necessary to know the dynamics of these metals in the soil, because they are results of interactions, such as: $\mathrm{pH}$, organic matter (OM), composition of clays, redox potential, competition in the adsorption sites, complexation with $\mathrm{OM}$, temperature, microbial activity and the tendency to form precipitates and coprecipitates (Kumpiene et al., 2007; Sipos et al., 2008).

The use of PS in the soil may act differently with respect to its solubility and bioavailability of $\mathrm{Cu}$ and $\mathrm{Zn}$ in the soil, compared with mineral fertilizers, because of the complexation of these metals with soil OM (Paradelo et al., 2011). The sequential extraction in the soil provides detailed information on origin, form of occurrence, availability, mobilization and transport of metals in natural environments (Mallmann et al., 2012; Souza et al., 2012).

Thus, this study aimed to determine the different forms of $\mathrm{Cu}$ and $\mathrm{Zn}$ in the soil and their absorption by bean plants in response to PS application compared with the mineral in the form of $\mathrm{Cu}$ and $\mathrm{Zn}$ oxide in Rhodic Kandiudox.

\section{Material AND Methods}

The experiment was carried out in a greenhouse, at the Embrapa Swine \& Poultry, in 2012, using a Rhodic Kandiudox (Nitossolo Vermelho Distroférrico) (EMBRAPA, 2013) collected in the surface layer of $0-20 \mathrm{~cm}$, in area of native vegetation that did not receive fertilizers or correctives, with the following chemical characteristics: $16 \mathrm{~g} \mathrm{~kg}^{-1}$ of SOM; $\mathrm{pH}$ in water of 4.6; $1.9 \mathrm{mg} \mathrm{dm}^{-3}$ of P; 0.8, 4.0, 1.1, 19.0 and $24.9 \mathrm{mmol}_{\mathrm{c}} \mathrm{dm}^{-3}$ of K, Ca, $\mathrm{Mg}$ (exchangeable), $\mathrm{H}+\mathrm{Al}$ and $\mathrm{CEC} \mathrm{pH} 7.0$, respectively, and $\mathrm{V}$ of $24 \%$, determined as described by Tedesco et al. (1995). The soil was maintained with natural $\mathrm{pH}$ because the highest absorption of $\mathrm{Cu}$ and $\mathrm{Zn}$ occurs in the $\mathrm{pH}$ range of 4.5 to 5.0, while base saturation was increased to $60 \%$ using agricultural gypsum.

The experiment was conducted in randomized block design in a $2 \times 3+1$ factorial scheme, with eight replicates. The treatments consisted of two types of fertilizers: mineral, composed of $\mathrm{Cu}$ and $\mathrm{Zn}$ oxide, and liquid pig slurry (PS), at three increasing doses equivalent to $1.7 / 6.0,3.4 / 12.0$ and $6.8 / 24.0 \mathrm{~kg} \mathrm{ha}^{-1}$ of $\mathrm{Cu} / \mathrm{Zn}$ in interaction between the nutrients, besides the control, without $\mathrm{Cu}$ and $\mathrm{Zn}$ only.
The chemical composition of the PS was determined according to Rice et al. (2012), with the following chemical characteristics: $5.1 \%(\mathrm{~m} / \mathrm{v})$ of dry matter, $4.5,0.99$ and 0.74 $\mathrm{kg} \mathrm{m}^{-3}$ of $\mathrm{N}, \mathrm{P}$ and $\mathrm{K}$; and 34 and $120 \mathrm{~g} \mathrm{~m}^{-3}$ of $\mathrm{Cu}$ and $\mathrm{Zn}$. N, $\mathrm{P}$ and $\mathrm{K}$ in the mineral treatment are present in the form of urea, triple superphosphate and potassium chloride, supplied to the soil in amounts equivalent to those added by the PS for each treatment.

The experimental units consisted of pots filled with 10.0 $\mathrm{kg}$ of soil, planted with eight seeds of 'Carioca' bean, cultivar 'BRS Estilo'. Sowing occurred on the same day of the application of the fertilizers in the soil; after germination, thinning was performed leaving only five seedlings per pot. During the experiment, the pots were maintained under intermittent irrigation in order to maintain soil moisture close to $80 \%$ of field capacity.

Bean plants were harvested after 55 days of cultivation. The plants were cut at the soil level for shoot biomass (S) and, for roots (R), the intact whole block of soil was removed from the pots and later separated and washed. Then, the materials were dried in forced-air oven at $65^{\circ} \mathrm{C}$ until constant mass. After drying, shoot and root dry biomass were determined on a precision scale, with two decimal places, and the contents of $\mathrm{Cu}$ and $\mathrm{Zn}$ were determined according to the methodology described by Tedesco et al. (1995).

Total and residual $\mathrm{Cu}$ and $\mathrm{Zn}$ contents in the soil were determined according to the methodology described by Ure (1990) through the aqua regia method. $\mathrm{Cu}$ and $\mathrm{Zn}$ fractionation followed the methodology described by Gomes et al. (1997), analyzing the fractions that are soluble, exchangeable, bound to organic matter and to the oxides of Fe and Al. The elements of the soluble fraction were extracted using KCI $(0.005 \mathrm{~mol}$ $\left.\mathrm{L}^{-1}\right)$; the elements of the exchangeable fraction were extracted using $\mathrm{BaCl}_{2}\left(0.1 \mathrm{~mol} \mathrm{~L}^{-1}\right)$, followed by agitation for $1 \mathrm{~h} ; \mathrm{Cu}$ and $\mathrm{Zn}$ bound to organic matter were extracted using $\mathrm{NaClO}(0.7$ $\mathrm{mol} \mathrm{L}-1)$ and placed in water bath at $90{ }^{\circ} \mathrm{C}$ for $15 \mathrm{~min}$, and the process was repeated twice and the extracts were combined; $\mathrm{Cu}$ and $\mathrm{Zn}$ bound to $\mathrm{Al}$ oxides were extracted using $\mathrm{NaOH}$ $\left(1.25 \mathrm{~mol} \mathrm{~L}^{-1}\right)$ and only then placed in water bath at $75{ }^{\circ} \mathrm{C}$ for $1 \mathrm{~h}$. $\mathrm{Cu}$ and $\mathrm{Zn}$ bound to Fe oxides were extracted using solution of ammonium oxalate $\left(0.2 \mathrm{~mol} \mathrm{~L}^{-1}\right)+$ oxalic acid $(0.2$ mol L $\left.{ }^{-1}\right)+$ ascorbic acid $\left(0.1 \mathrm{~mol} \mathrm{~L}^{-1}\right)$ followed by agitation in the dark, for $4 \mathrm{~h}$.

Between each fractionation step, the soil was washed with distilled water, centrifuged and the supernatant was discarded. Then, the soil was dried and the samples were weighed before each extraction step to calculate the contents of $\mathrm{Cu}$ and $\mathrm{Zn}$, since there may be removal of part of the mineral and organic phases by the extractors in the successive extractions. The samples of each fraction were centrifuged at $2000 \mathrm{rpm}$ at 670 $\mathrm{x} g$ for $20 \mathrm{~min}$, the extracts were filtered and the volume was replenished with $3 \mathrm{~mol} \mathrm{~L}^{-1} \mathrm{HNO}_{3}$ to $50 \mathrm{~mL}$, being later analyzed in atomic absorption spectrophotometer.

The data were subjected to analysis of variance homogeneity and normality. Data transformation was not necessary; after the parametric assumptions were met, the results were subjected to analysis of variance by F test and, when there was difference, the means were compared by Tukey test $(\mathrm{p}<0.05)$. Additionally, 
regression analysis was performed to verify the behavior of the variable as a function of the increasing doses applied in the soil.

\section{Results AND Discussion}

There was interaction for the variables total $\mathrm{Cu}$ and $\mathrm{Cu}$ in exchangeable, organic matter, Fe oxide and residual fractions (Table 1). For total $\mathrm{Cu}$, fertilization with PS and as $\mathrm{Cu}$ oxide showed increasing quadratic behavior, with maximum responses at the doses of 5.8 and $6.8 \mathrm{~kg} \mathrm{ha}^{-1}$ of Cu for oxide and PS, respectively; the contents for PS were superior to those for $\mathrm{Cu}$ oxide at the applied doses. It should be pointed out that, for the form of $\mathrm{Cu}$ oxide, the highest contents were observed at the doses of 3.4 and $6.8 \mathrm{~kg} \mathrm{ha}^{-1}$, while for PS the highest content occurred at the highest dose.

$\mathrm{Cu}$ application in the form of oxide or PS until the highest dose (equivalent to $6.8 \mathrm{~kg} \mathrm{ha}^{-1}$ ) did not interfere with the content of soluble $\mathrm{Cu}$, and only traces of the element were found (Table 1). The low contents in this fraction may have occurred because the applied doses were not sufficient to occupy all bonding sites in the soil and allow the increase in the soluble fraction. The content of $\mathrm{Cu}$ in the free form is extremely low due to its affinity with organic and mineral compounds of the soil (Sipos et al., 2008; Muñoz et al., 2008).

The content of exchangeable $\mathrm{Cu}$ in the soil showed increasing quadratic behavior, with maximum response at the dose of $6.8 \mathrm{~kg} \mathrm{ha}^{-1}$ in both treatments; PS was superior to the mineral in the form of $\mathrm{Cu}$ oxide with respect to the availability of this micronutrient with emphasis for doses equal to or higher than $3.4 \mathrm{~kg} \mathrm{ha}^{-1}$ (Table 1). The slight increase in the content of exchangeable $\mathrm{Cu}$ when soluble mineral sources are applied is related to its adsorption to soil colloids, covalently, leaving it little available, which does not occur with the organic form, which preserves this micronutrient in structures with organic C, avoiding its fixation in the soil (Ceretta et al., 2010; Bertol et al., 2010).

With the increase in $\mathrm{Cu}$ doses in the soil, there was an increasing quadratic response in $\mathrm{Cu}$ bound to soil organic matter (SOM) only for PS, with maximum response at the dose of $3.6 \mathrm{~kg} \mathrm{ha}^{-1}$ (Table 1). The lowest contents of $\mathrm{Cu}$ bound to SOM for the application of PS, in comparison to the mineral of $\mathrm{Cu}$ oxide, may be related to the fact that this element is bound to carbonic structures present in the PS.

OM has large specific surface, negative net charge dependent on $\mathrm{pH}$, ease of imbibition of water and soil solution containing metals and capacity to form organic chelates (Plaza et al., 2013). Cu can be complexed to OM in insoluble organic forms, being little available. The main bond of $\mathrm{Cu}$ in the $\mathrm{OM}$ is in the organic acids of higher molecular weight forming stable complexes of high energy (Pires \& Mattiazzo, 2007; Ceretta et al., 2010). In Cu-deficient soils, the bonding force decreases with the increase of the applied amount, but increases with the higher degree of humification and with $\mathrm{pH}$ (Kumpiene et al., 2007; Muñoz et al., 2008).

Only the application of increasing doses of $\mathrm{Cu}$ in the form of PS increased the content of $\mathrm{Cu}$ bound to Fe oxides in the soil, with increasing quadratic behavior and highest content at the highest dose (Table 1). The highest $\mathrm{Cu}$ contents in this

Table 1. Copper $(\mathrm{Cu})$ content in different soil fractions in response to the application of different doses of this element in the forms of mineral oxide or pig slurry

\begin{tabular}{|c|c|c|c|c|c|}
\hline \multirow{2}{*}{ Fertilizer } & \multicolumn{4}{|c|}{ Dose $\left(\mathrm{kg} \mathrm{ha}^{-1}\right)$} & \multirow[b]{2}{*}{ Regression equation } \\
\hline & 0 & 1.7 & 3.4 & 6.8 & \\
\hline \multicolumn{6}{|c|}{ Total $\left(\mathrm{mg} \mathrm{kg}^{-1}\right)$} \\
\hline Cu oxide & $169.4 \mathrm{C}$ & $172.9 \mathrm{Bb}$ & $178.4 \mathrm{Ba}$ & $179.8 \mathrm{Ba}$ & $\hat{y}=169+3.5 x-0.3 x^{2} \quad R^{2}=0.90$ \\
\hline Pig slurry & $169.4 d$ & $181.8 \mathrm{Ac}$ & $185.4 \mathrm{Ab}$ & $194.8 \mathrm{Aa}$ & $\hat{y}=170.2+6.3 x-0.4 x^{2} \quad R^{2}=0.93$ \\
\hline Mean & $169.4 \mathrm{~d}$ & $177.4 \mathrm{c}$ & $181.9 \mathrm{~b}$ & $187.3 \mathrm{a}$ & \\
\hline \multicolumn{6}{|c|}{ Soluble $\left(\mathrm{mg} \mathrm{kg}^{-1}\right)$} \\
\hline Cu oxide & nd & nd & nd & nd & nd \\
\hline Pig slurry & nd & nd & nd & nd & nd \\
\hline Mean & nd & nd & nd & nd & \\
\hline \multicolumn{6}{|c|}{ Exchangeable $\left(\mathrm{mg} \mathrm{kg}^{-1}\right)$} \\
\hline Cu oxide & $0.27 \mathrm{c}$ & $0.30 \mathrm{bc}$ & $0.32 \mathrm{Bab}$ & $0.36 \mathrm{Ba}$ & $\hat{y}=0.3+0.02 x-0.0009 x^{2} \quad R^{2}=0.67$ \\
\hline Pig slurry & $0.27 \mathrm{~d}$ & $0.33 \mathrm{c}$ & $0.51 \mathrm{Ab}$ & $0.77 \mathrm{Aa}$ & $\hat{y}=0.3+0.06 x+0.002 x^{2} \quad R^{2}=0.97$ \\
\hline Mean & $0.27 \mathrm{~d}$ & $0.30 \mathrm{c}$ & $0.42 \mathrm{~b}$ & $0.56 \mathrm{a}$ & \\
\hline \multicolumn{6}{|c|}{ Organic matter $\left(\mathrm{mg} \mathrm{kg}^{-1}\right)$} \\
\hline Cu oxide & $6.41 \mathrm{~b}$ & $5.60 \mathrm{Ab}$ & $6.99 \mathrm{Aa}$ & $6.37 \mathrm{Aa}$ & $\bar{y}=6.34$ \\
\hline Pig slurry & $6.41 \mathrm{~b}$ & $4.18 \mathrm{Bc}$ & $5.62 \mathrm{Ba}$ & $5.64 \mathrm{Ba}$ & $\hat{y}=6.0-0.65 x+0.09 x^{2} \quad R^{2}=0.31$ \\
\hline Mean & $6.41 \mathrm{~b}$ & $4.89 \mathrm{c}$ & $6.31 \mathrm{a}$ & $6.00 \mathrm{a}$ & \\
\hline \multicolumn{6}{|c|}{ Aluminum oxide $\left(\mathrm{mg} \mathrm{kg}^{-1}\right)$} \\
\hline Cu oxide & nd & nd & nd & nd & nd \\
\hline Pig slurry & nd & nd & nd & nd & nd \\
\hline Mean & nd & nd & nd & nd & \\
\hline \multicolumn{6}{|c|}{ Iron oxide $\left(\mathrm{mg} \mathrm{kg}^{-1}\right)$} \\
\hline Cu oxide & $51.2 \mathrm{~b}$ & 47.1 Bc & $53.1 \mathrm{Ba}$ & $55.6 \mathrm{Ba}$ & $\bar{y}=52.3$ \\
\hline Pig slurry & $51.2 \mathrm{c}$ & $52.8 \mathrm{Ac}$ & $57.6 \mathrm{Ab}$ & $62.3 \mathrm{Aa}$ & $\hat{y}=50.9+1.7 x-0.007 x^{2} \quad R^{2}=0.84$ \\
\hline Mean & $51.2 \mathrm{~b}$ & $50.5 b$ & $55.9 \mathrm{a}$ & $58.5 \mathrm{a}$ & \\
\hline \multicolumn{6}{|c|}{ Residual $\left(\mathrm{mg} \mathrm{kg}^{-1}\right)$} \\
\hline Cu oxide & $111.2 b$ & $118.9 \mathrm{Ba}$ & $116.7 \mathrm{Ba}$ & $117.5 \mathrm{Ba}$ & $\bar{y}=116.2$ \\
\hline Pig slurry & $111.2 \mathrm{~b}$ & $124.5 \mathrm{Aa}$ & $121.8 \mathrm{Aa}$ & $126.1 \mathrm{Aa}$ & $\hat{y}=118.5$ \\
\hline Mean & $111.2 \mathrm{a}$ & $121.7 \mathrm{a}$ & $119.3 \mathrm{a}$ & $121.8 \mathrm{a}$ & \\
\hline
\end{tabular}

Means followed by different letters (lowercase in rows and uppercase in columns) differ ( $\leq \leq 0.05)$ by Tukey test; nd - Value below the detection limit of the analytical method 
mineral fraction of the soil occurred with the application of $\mathrm{Cu}$ in the form of PS, in relation to the form of oxide, at both doses.

The contents of $\mathrm{Cu}$ bound to $\mathrm{Al}$ oxides were below the detection limit of the analytical method, and only traces of this element were found (Table 1). Similar response in this fraction occurred for $\mathrm{Zn}$ in the soil (Table 4). The lack of interference of the application of $\mathrm{Cu}$ and $\mathrm{Zn}$ in the form of oxide or PS in the soil in this mineral fraction may be due to the predominance, at higher proportions in the clay fraction, of crystalline forms of Fe in relation to those of $\mathrm{Al}$.

There was an increase in $\mathrm{Cu}$ content in the residual fraction with the $\mathrm{Cu}$ doses only with the application of PS (Table 1). This fraction is considered as inert and is not extracted in the other steps of the fractionation, but is considered as a chemically stable and biologically inactive fraction (Sipos et al., 2008; Souza et al., 2012).

Most of the $\mathrm{Cu}$ in the soil was found in the residual fraction, followed by Fe oxides, organic and exchangeable, indicating a strong $\mathrm{Cu}$ adsorption to the functional groups of the soil (Table 1), with predominance of the fraction of Fe oxides. $\mathrm{Cu}$ is adsorbed in the soil through covalent bonds, being strongly retained and forming complexes of high bonding energy, especially on surfaces containing hydroxyl groups, such as in hydroxides and oxyhydroxides of $\mathrm{Fe}, \mathrm{Al}$ and $\mathrm{Mn}$ (Mallmann et al., 2012).

There was no difference in the content of $\mathrm{Cu}$ in the shoots of bean plants in response to the application of $\mathrm{Cu}$ in the soil in the form of oxide or PS (Table 2); however, for the root, there was increasing quadratic behavior in the $\mathrm{Cu}$ content, with maximum response at the $\mathrm{Cu}$ doses of 3.3 and $6.8 \mathrm{~kg}$ $\mathrm{ha}^{-1}$ for the fertilizer in the form of oxide and PS, respectively.

The application of PS promoted greater accumulation of $\mathrm{Cu}$ in shoots and roots, with increasing quadratic behavior and maximum accumulation at the doses of 5.5 and $5.0 \mathrm{~kg} \mathrm{ha}^{-1}$ for bean shoots and roots, respectively (Table 3 ). Cu accumulation in bean plants is related to the availability of this micronutrient in the soil, mainly represented by the exchangeable fraction (Table 1).

The total $\mathrm{Zn}$ content in the soil showed an increasing quadratic behavior, with maximum response at the doses of 20 and $24 \mathrm{~kg} \mathrm{ha}^{-1}$ of $\mathrm{Zn}$ in the form of oxide and PS, respectively; the treatment with $\mathrm{Zn}$ oxide was superior to that with PS in the availability of this micronutrients at the applied doses (Table 4). The highest $\mathrm{Zn}$ availability in the soil, demonstrated by the total contents in the mineral fertilizer in relation to PS, is related to the complexation of this micronutrient by carbon chains present in the PS, unlike the form of $\mathrm{Zn}$ oxide.

The content of soluble $\mathrm{Zn}$ in the soil increased in a similar way in both treatments, with slight superiority for PS at the doses of 6 and $24 \mathrm{~kg} \mathrm{ha}^{-1}$ and for the mineral in the form of $\mathrm{Zn}$ oxide at the dose of $12 \mathrm{~kg} \mathrm{ha}^{-1}$ (Table 4). For this fraction, there was an increasing quadratic response, with highest $\mathrm{Zn}$ content at the highest dose in both treatments. Unlike $\mathrm{Cu}$ in the soil, $\mathrm{Zn}$ is more weakly bound to clay minerals and adsorbents in the form of oxides, hydroxides and oxyhydroxides in the soil, making this metal more labile and bioavailable (Sipos et al., 2008; Paradelo et al., 2011; Mallmann et al., 2012), which explains the higher presence of this element in the soluble and exchangeable fractions of the soil.

Total $\mathrm{Zn}$, exchangeable $\mathrm{Zn}$ and $\mathrm{Zn}$ bound to $\mathrm{Fe}$ oxides in the soil showed the highest contents with the application of $\mathrm{Zn}$ in the form of oxide (Table 4). The lower intensity of bonding force of $\mathrm{Zn}$ to soil colloids, compared with $\mathrm{Cu}$ (Sipos et al., 2008; Uprety et al., 2009), allows the mineral fertilizer to promote greater availability, a condition that occurred in the three forms of $\mathrm{Zn}$ in the soil

Table 2. Copper $(\mathrm{Cu})$ contents in shoots and roots of bean plants in response to the application of different doses of this element in the soil in the forms of mineral oxide or pig slurry

\begin{tabular}{|c|c|c|c|c|c|}
\hline \multirow{2}{*}{ Fertilizer } & \multicolumn{4}{|c|}{ Dose $\left(\mathrm{kg} \mathrm{ha}^{-1}\right)$} & \multirow{2}{*}{ Regression equation } \\
\hline & 0 & 1.7 & 3.4 & 6.8 & \\
\hline \multicolumn{6}{|c|}{ Shoots $\left(\mathrm{mg} \mathrm{kg}^{-1}\right)$} \\
\hline Cu oxide & 10.9 & 10.5 & 10.0 & 10.7 & $\hat{y}=10.6$ \\
\hline Pig slurry & 11.2 & 10.5 & 10.6 & 11.1 & $\hat{y}=10.9$ \\
\hline Mean & 11.0 & 10.5 & 10.3 & 10.9 & \\
\hline \multicolumn{6}{|c|}{ Roots $\left(\mathrm{mg} \mathrm{kg}^{-1}\right)$} \\
\hline Cu oxide & $67.5 \mathrm{c}$ & $110.7 \mathrm{Aa}$ & $89.0 \mathrm{~b}$ & $72.1 \mathrm{Bc}$ & $\hat{y}=73.5+16.7 x-2.5 x^{2} \quad R^{2}=0.57$ \\
\hline Pig slurry & $67.5 \mathrm{c}$ & 74.1 Bc & $88.1 \mathrm{~b}$ & 101.2 Aa & $y=66.5+6.4 x-0.2 x^{2} \quad R^{2}=0.93$ \\
\hline Mean & $67.5 \mathrm{c}$ & $92.4 \mathrm{a}$ & $88.6 \mathrm{ab}$ & $86.7 \mathrm{~b}$ & \\
\hline
\end{tabular}

Means followed by different letters (lowercase in rows and uppercase in columns) differ $(p \leq 0.05)$ by Tukey test

Table 3. Copper $(\mathrm{Cu})$ accumulation in shoots and roots of bean plants in response to the application of doses of this element in the forms of mineral oxide or pig slurry

\begin{tabular}{|c|c|c|c|c|c|}
\hline \multirow{2}{*}{ Fertilizer } & \multicolumn{4}{|c|}{ Dose (kg ha-1) } & \multirow{2}{*}{ Regression equation } \\
\hline & 0 & 1.7 & 3.4 & 6.8 & \\
\hline \multicolumn{6}{|c|}{ Shoots (mg pot $\left.{ }^{-1}\right)$} \\
\hline Cu oxide & $0.17 \mathrm{~b}$ & $0.20 \mathrm{Ba}$ & $0.20 \mathrm{Ba}$ & $0.20 \mathrm{Ba}$ & $\hat{y}=0.19$ \\
\hline Pig slurry & $0.17 \mathrm{~d}$ & $0.25 \mathrm{Ac}$ & $0.42 \mathrm{Aa}$ & $0.33 \mathrm{Ab}$ & $\hat{y}=0.2+0.11 x-0.01 x^{2} \quad R^{2}=0.84$ \\
\hline Mean & $0.17 \mathrm{~d}$ & $0.22 \mathrm{c}$ & $0.31 \mathrm{a}$ & $0.26 b$ & \\
\hline \multicolumn{6}{|c|}{ Roots $\left(\mathrm{mg} \mathrm{pot}^{-1}\right)$} \\
\hline Cu oxide & $0.22 d$ & $0.39 \mathrm{Aa}$ & $0.31 \mathrm{Bb}$ & $0.25 \mathrm{Bc}$ & $\hat{y}=0.2+0.06 x-0.01 x^{2} \quad R^{2}=0.54$ \\
\hline Pig slurry & $0.22 \mathrm{c}$ & $0.33 \mathrm{Bb}$ & $0.42 \mathrm{Aa}$ & $0.41 \mathrm{Aa}$ & $\hat{y}=0.2+0.08 x-0.008 x^{2} \quad R^{2}=0.97$ \\
\hline Mean & $0.22 \mathrm{C}$ & $0.36 \mathrm{a}$ & $0.36 \mathrm{a}$ & $0.33 \mathrm{~b}$ & \\
\hline
\end{tabular}

Means followed by different letters (lowercase in rows and uppercase in columns) differ ( $p \leq 0.05)$ by Tukey test 
Table 4. Zinc (Zn) contents in different soil fractions in response to the application of different doses of this element in the forms of mineral oxide or pig slurry

\begin{tabular}{|c|c|c|c|c|c|}
\hline \multirow{2}{*}{ Fertilizer } & \multicolumn{4}{|c|}{ Dose $\left(\mathrm{kg} \mathrm{ha}^{-1}\right)$} & \multirow[b]{2}{*}{ Regression equation } \\
\hline & 0 & 6 & 12 & 24 & \\
\hline \multicolumn{6}{|c|}{ Total $\left(\mathrm{mg} \mathrm{kg}^{-1}\right)$} \\
\hline Zn oxide & $101.3 d$ & $109.7 \mathrm{Ac}$ & $114.3 \mathrm{Ab}$ & $116.6 \mathrm{Aa}$ & $\hat{y}=101.4+1.6 x-0.04 x^{2} \quad R^{2}=0.96$ \\
\hline Pig slurry & $101.3 d$ & 106.7 Bc & $108.9 \mathrm{Bb}$ & $114.4 \mathrm{Ba}$ & $\hat{y}=101.7+0.8 x-0.01 x^{2} \quad R^{2}=0.92$ \\
\hline Mean & $101.3 \mathrm{~d}$ & $108.2 \mathrm{c}$ & $111.6 \mathrm{~b}$ & $115.5 \mathrm{a}$ & \\
\hline \multicolumn{6}{|c|}{ Soluble $\left(\mathrm{mg} \mathrm{kg}^{-1}\right)$} \\
\hline Zn oxide & $0.34 \mathrm{~d}$ & $0.50 \mathrm{Bc}$ & $0.98 \mathrm{Ab}$ & $1.22 \mathrm{Ba}$ & $\hat{y}=0.3+0.06 x-0.0008 x^{2} \quad R^{2}=0.92$ \\
\hline Pig slurry & $0.34 \mathrm{~d}$ & $0.60 \mathrm{Ac}$ & $0.70 \mathrm{Bb}$ & $1.42 \mathrm{Aa}$ & $\hat{y}=0.4+0.02 x-0.001 x^{2} \quad R^{2}=0.98$ \\
\hline Mean & $0.34 \mathrm{~d}$ & $0.55 \mathrm{c}$ & $0.84 \mathrm{~b}$ & $1.32 \mathrm{a}$ & \\
\hline \multicolumn{6}{|c|}{ Exchangeable $\left(\mathrm{mg} \mathrm{kg}^{-1}\right)$} \\
\hline Zn oxide & $1.59 \mathrm{c}$ & $2.11 \mathrm{C}$ & $5.52 \mathrm{Ab}$ & $7.53 \mathrm{Aa}$ & $\hat{y}=1.2+0.3 x-0.002 x^{2} \quad R^{2}=0.92$ \\
\hline Pig slurry & $1.59 \mathrm{~d}$ & $2.50 \mathrm{C}$ & $4.26 \mathrm{Bb}$ & $7.02 \mathrm{Ba}$ & $\hat{y}=1.5+0.2 x-0.001 x^{2} \quad R^{2}=0.97$ \\
\hline Mean & $1.59 \mathrm{~d}$ & $2.30 \mathrm{c}$ & $4.89 \mathrm{~b}$ & $7.28 \mathrm{a}$ & \\
\hline \multicolumn{6}{|c|}{ Organic matter $\left(\mathrm{mg} \mathrm{kg}^{-1}\right)$} \\
\hline Zn oxide & $0.99 \mathrm{a}$ & $0.77 \mathrm{Ab}$ & $0.67 \mathrm{Ab}$ & $0.36 \mathrm{Ac}$ & $\hat{y}=0.98-0.03 x-0.0002 x^{2} \quad R^{2}=0.91$ \\
\hline Pig slurry & $0.99 \mathrm{a}$ & $0.27 \mathrm{Bb}$ & $0.04 \mathrm{BC}$ & $0.04 \mathrm{Bc}$ & $\hat{y}=0.96-0.12 x-0.004 x^{2} \quad R^{2}=0.97$ \\
\hline Mean & $0.99 \mathrm{a}$ & $0.52 \mathrm{~b}$ & $0.35 \mathrm{C}$ & $0.20 \mathrm{~d}$ & \\
\hline \multicolumn{6}{|c|}{ Aluminum oxide $\left(\mathrm{mg} \mathrm{kg}^{-1}\right)$} \\
\hline Zn oxide & $\mathrm{Nd}$ & nd & nd & nd & nd \\
\hline Pig slurry & $\mathrm{Nd}$ & nd & nd & nd & nd \\
\hline Mean & $\mathrm{Nd}$ & nd & nd & nd & \\
\hline \multicolumn{6}{|c|}{ Iron oxide $\left(\mathrm{mg} \mathrm{kg}^{-1}\right)$} \\
\hline Zn oxide & $13.9 \mathrm{~d}$ & 18.6 Ac & $20.2 \mathrm{Ab}$ & $22.8 \mathrm{Aa}$ & $\hat{y}=14.1-0.7 x-0.02 x^{2} \quad R^{2}=0.93$ \\
\hline Pig slurry & $13.9 \mathrm{c}$ & $14.4 \mathrm{Bc}$ & $18.1 \mathrm{Bb}$ & $19.8 \mathrm{Ba}$ & $\hat{y}=13.4+0.4 x-0.004 x^{2} \quad R^{2}=0.82$ \\
\hline Mean & $13.9 \mathrm{~d}$ & $16.5 \mathrm{c}$ & $19.2 \mathrm{~b}$ & $21.3 \mathrm{a}$ & \\
\hline \multicolumn{6}{|c|}{ Residual $\left(\mathrm{mg} \mathrm{kg}^{-1}\right)$} \\
\hline Zn oxide & $84.5 b$ & $87.8 \mathrm{a}$ & $86.9 \mathrm{ab}$ & $84.7 \mathrm{~b}$ & $\hat{y}=84.8+0.05 x-0.002 x^{2} \quad R^{2}=0.41$ \\
\hline Pig slurry & $84.5 b$ & $89.0 \mathrm{a}$ & $85.7 \mathrm{~b}$ & $86.0 \mathrm{~b}$ & $\bar{y}=86.3$ \\
\hline Mean & $84.5 \mathrm{C}$ & $88.4 \mathrm{a}$ & $86.3 \mathrm{~b}$ & 85.4 bc & \\
\hline
\end{tabular}

Means followed by different letters (lowercase in rows and uppercase in columns) differ ( $\leq 0.05)$ by Tukey test; nd - Value below the detection limit of the analytical method

The application of increasing doses of $\mathrm{Zn}$ in the soil in the form of oxide or PS resulted in decrease of the $\mathrm{Zn}$ bound to SOM, and the doses of 24 and $15 \mathrm{~kg} \mathrm{ha}^{-1}$ showed lower reduction (Table 4). The reduction in the content of $\mathrm{Zn}$ bound to SOM, in both cases, can be related to the displacement of this organic form to the exchangeable and soluble forms, resulting in greater availability to the plant.

For the fraction of residual $\mathrm{Zn}$ in the soil, there was an increasing quadratic response for $\mathrm{Zn}$ added in the form of oxide, with maximum content obtained at the dose of 12.5 $\mathrm{kg} \mathrm{ha}^{-1}$, and there was no response for PS (Table 4). In the condition of residual $\mathrm{Zn}$, there was small interference in relation to the increase of the doses of this micronutrient in the soil, in both organic and mineral forms.

For $\mathrm{Zn}$ contents in the shoots of bean plants, there was a decreasing quadratic behavior in both treatments as a function of the applied $\mathrm{Zn}$ doses, and the highest contents were observed in the absence of application of this element in the soil (Table 5), while in the roots there was an increasing quadratic behavior, with the highest $\mathrm{Zn}$ contents at the highest dose applied in both treatments.

PS application resulted in greater $\mathrm{Zn}$ accumulation in both shoots and roots of bean plants, with increasing quadratic behavior, and the most effective dose was $24 \mathrm{~kg} \mathrm{ha}^{-1}$ in both treatments (Table 6), although the mineral treatment in the form of oxide showed higher $\mathrm{Zn}$ content in the forms of total, exchangeable and bound to Fe oxides (Table 4).

The application of increasing doses of PS in the soil resulted in greater production of shoot and root dry biomass in bean plants, in relation to the form of oxide, with increasing quadratic behavior (Table 7), and the dose of $3.4 / 12 \mathrm{~kg} \mathrm{ha}^{-1}$ of $\mathrm{Cu} / \mathrm{Zn}$ showed the highest response. At the doses of $6.8 / 24 \mathrm{~kg}$ $\mathrm{ha}^{-1}$ of $\mathrm{Cu} / \mathrm{Zn}$ in the form of oxide and PS, there was a decrease in the production of shoot dry biomass, demonstrating probable effect of toxicity.

Table 5. Zinc (Zn) contents in shoots and roots of bean plants in response to the application of different doses of this element in the soil in the forms of mineral oxide or pig slurry

\begin{tabular}{|c|c|c|c|c|c|}
\hline \multirow{2}{*}{ Fertilizer } & \multicolumn{4}{|c|}{ Dose $\left(\mathrm{kg} \mathrm{ha}^{-1}\right)$} & \multirow{2}{*}{ Regression equation } \\
\hline & 0 & 6 & 12 & 24 & \\
\hline \multicolumn{6}{|c|}{ Shoots $\left(\mathrm{mg} \mathrm{kg}^{-1}\right)$} \\
\hline Zn oxide & $434.1 \mathrm{a}$ & $227.5 \mathrm{Bd}$ & $276.0 \mathrm{Ac}$ & $355.9 \mathrm{Ab}$ & $\hat{y}=412.7-27.8 x+1.1 x^{2} \quad R^{2}=0.72$ \\
\hline Pig slurry & $434.1 \mathrm{a}$ & $281.7 \mathrm{Ab}$ & $163.2 \mathrm{Bc}$ & $292.1 \mathrm{Bb}$ & $\hat{y}=441.3-37.6 x+1.3 x^{2} \quad R^{2}=0.94$ \\
\hline Mean & $434.1 \mathrm{a}$ & $254.6 \mathrm{c}$ & $219.6 \mathrm{~d}$ & $324.0 \mathrm{~b}$ & \\
\hline \multicolumn{6}{|c|}{ Roots $\left(\mathrm{mg} \mathrm{kg}^{-1}\right)$} \\
\hline Zn oxide & $72.2 \mathrm{~d}$ & $158.3 \mathrm{Ac}$ & $171.1 \mathrm{~b}$ & $261.6 \mathrm{a}$ & $\hat{y}=80+10.3 x-0.1 x^{2} \quad R^{2}=0.94$ \\
\hline Pig slurry & $72.2 \mathrm{~d}$ & $106.3 \mathrm{Bc}$ & $164.4 \mathrm{~b}$ & $264.2 \mathrm{a}$ & $\hat{y}=69.8+6.8 x-0.05 x^{2} \quad R^{2}=0.99$ \\
\hline Mean & $72.2 \mathrm{~d}$ & $132.3 \mathrm{c}$ & $167.7 \mathrm{~b}$ & $262.9 \mathrm{a}$ & \\
\hline
\end{tabular}

Means followed by different letters (lowercase in rows and uppercase in columns) differ ( $\mathrm{p} \leq 0.05)$ by Tukey test 
Table 6. Zinc (Zn) accumulation in shoots and roots of bean plants in response to the application of different doses of this element in the soil in the forms of mineral oxide or pig slurry

\begin{tabular}{|c|c|c|c|c|c|}
\hline \multirow{2}{*}{ Fertilizer } & \multicolumn{4}{|c|}{ Dose (kg ha-1) } & \multirow{2}{*}{ Regression equation } \\
\hline & 0 & 6 & 12 & 24 & \\
\hline \multicolumn{6}{|c|}{ Shoots $\left(\mathrm{mg} \mathrm{pot}^{-1}\right)$} \\
\hline Zn oxide & $6.4 \mathrm{a}$ & $4.3 \mathrm{Bc}$ & $5.6 \mathrm{Bb}$ & $6.7 \mathrm{Ba}$ & $\hat{y}=6.1-0.2 x+0.01 x^{2} \quad R^{2}=0.54$ \\
\hline Pig slurry & $6.4 \mathrm{~b}$ & $6.6 \mathrm{Ab}$ & $6.5 \mathrm{Ab}$ & $8.6 \mathrm{Aa}$ & $\hat{y}=6.5-0.06 x+0.006 x^{2} \quad R^{2}=0.81$ \\
\hline Mean & $6.4 \mathrm{~b}$ & $5.5 \mathrm{c}$ & $6.1 \mathrm{~b}$ & $7.6 \mathrm{a}$ & \\
\hline \multicolumn{6}{|c|}{ Roots $\left(\mathrm{mg} \mathrm{pot}^{-1}\right)$} \\
\hline Zn oxide & $0.24 \mathrm{C}$ & $0.56 \mathrm{Ab}$ & $0.59 \mathrm{Bb}$ & $0.92 \mathrm{Ba}$ & $\hat{y}=0.3+0.04 x-0.0005 x^{2} \quad R^{2}=0.94$ \\
\hline Pig slurry & $0.24 \mathrm{~d}$ & $0.47 \mathrm{Bc}$ & $0.78 \mathrm{Ab}$ & $1.08 \mathrm{Aa}$ & $\hat{y}=0.2+0.05 x-0.0007 x^{2} \quad R^{2}=0.99$ \\
\hline Mean & $0.24 \mathrm{~d}$ & $0.52 \mathrm{c}$ & $0.69 \mathrm{~b}$ & $1.00 \mathrm{a}$ & \\
\hline
\end{tabular}

Means followed by different letters (lowercase in rows and uppercase in columns) differ ( $\leq 0.05)$ by Tukey test

Table 7. Shoot and root dry biomass of bean plants in response to the application of different doses of copper $(\mathrm{Cu})$ and zinc $(\mathrm{Zn})$ in the forms of mineral oxide or pig slurry

\begin{tabular}{|c|c|c|c|c|c|}
\hline \multirow{2}{*}{ Fertilizer } & \multicolumn{4}{|c|}{ Cu and $\mathrm{Zn}$ dose $\left(\mathrm{kg} \mathrm{ha}^{-1}\right)$} & \multirow{2}{*}{ Regression equation } \\
\hline & 0 & $1.7 / 6$ & $3.4 / 12$ & $6.8 / 24$ & \\
\hline \multicolumn{6}{|c|}{ Shoots $\left(\mathrm{g} \mathrm{pot}^{-1}\right)$} \\
\hline Cu/Zn oxide & 14.85 & 18.74 & $20.48 B$ & $18.85 \mathrm{~B}$ & $\hat{y}=13.1+3.2 x-0.1 x^{2} \quad R^{2}=0.96$ \\
\hline Pig slurry & $14.85 \mathrm{C}$ & $23.60 \mathrm{bc}$ & $39.79 \mathrm{Aa}$ & $29.43 \mathrm{Ab}$ & $\hat{y}=14.9+0.8 x-0.03 x^{2} \quad R^{2}=0.96$ \\
\hline Mean & $14.85 \mathrm{~b}$ & $21.17 \mathrm{~b}$ & $30.14 \mathrm{a}$ & $24.14 \mathrm{ab}$ & \\
\hline \multicolumn{6}{|c|}{ Roots $\left(\mathrm{g} \mathrm{pot}^{-1}\right)$} \\
\hline Cu/Zn oxide & 3.33 & $3.56 \mathrm{~B}$ & $3.46 \mathrm{~B}$ & 3.50 & $\hat{y}=3.4+0.02 x-0.0007 x^{2} \quad R^{2}=0.52$ \\
\hline Pig slurry & $3.33 \mathrm{~b}$ & $5.33 \mathrm{Aa}$ & $6.03 \mathrm{Aa}$ & $4.66 \mathrm{a}$ & $\hat{y}=3.4+0.4 x-0.01 x^{2} \quad R^{2}=0.99$ \\
\hline Mean & 3.33 & 4.45 & 4.75 & 4.08 & \\
\hline
\end{tabular}

Means followed by different letters (lowercase in rows and uppercase in columns) differ ( $x \leq 0.05)$ by Tukey test

\section{Conclusions}

1. The application of $\mathrm{Cu}$ in the form of pig slurry (PS) increased $\mathrm{Cu}$ contents in the soil in the fractions available, exchangeable, $\mathrm{Fe}$ oxides and residual, while its application in the form of oxide increased $\mathrm{Cu}$ contents in the fraction associated with soil organic matter (SOM).

2. The $\mathrm{Zn}$ contents in the fractions available, exchangeable and SOM were higher when $\mathrm{Zn}$ was applied in the form of oxide, and higher in the soluble fraction when $\mathrm{Zn}$ was applied in the form of PS.

3. Among the evaluated fractions, the main bond of $\mathrm{Cu}$ and $\mathrm{Zn}$ in the soils occurred with Fe oxides, regardless of the source, for the condition of a Rhodic Kandiudox.

4. The highest content of $\mathrm{Cu}$ available in the soil occurred when it was applied in the form of PS and, for $\mathrm{Zn}$, in the form of oxide, reflecting in the higher absorption of these nutrients by the bean plants.

\section{Literature Cited}

Bertol, O. J.; Fey, E.; Favaretto, N.; Lavoranti, J.; Rizzi, N. E. Mobilidade de $\mathrm{P}, \mathrm{Cu}$ e $\mathrm{Zn}$ em colunas de solo sob sistema de semeadura direta submetido às adubações mineral e orgânica. Revista Brasileira de Ciência do Solo, v.34, p.1841-1850, 2010. http://dx.doi. org/10.1590/S0100-06832010000600008

EMBRAPA - Empresa Brasileira de Pesquisa Agropecuária. Centro Nacional de Pesquisa de Solos. Sistema brasileiro de classificação de solos. 3.ed. Rio de Janeiro: EMBRAPA, 2013. 353p.

Ceretta, C. A.; Girotto, E.; Lourenzi, C. R.; Trentin, G.; Vieira, R. C. B.; Brunetto, G. Nutrients transfer by runoff under no tillage in a soil treated with successive applications of pig slurry. Agriculture, Ecosystems \& Environment, v.139, p.689-699, 2010. http://dx.doi. org/10.1016/j.agee.2010.10.016
Girotto, E.; Ceretta, C. A.; Brunetto, G.; Rheinheimer, D. S.; Silva, L. S.; Lourenzi, C. R.; Lorensini, F.; Vieira, R. C. B.; Schmatz, R. Acúmulo e formas de cobre e zinco no solo após aplicações sucessivas de dejeto líquido de suínos. Revista Brasileira de Ciência do Solo, v.34, p.955-965, 2010. http://dx.doi.org/10.1590/ S0100-06832010000300037

Gomes, P. C.; Fontes, M. P. F.; Costa, L. M. da; Mendonça, E. de S. Extração fracionada de metais pesados em Latossolo VermelhoAmarelo. Revista Brasileira de Ciência do Solo, v.21, p.543-551, 1997. http://dx.doi.org/10.1590/S0100-06831997000400003

Kumpiene, J.; Montesinos, I. C.; Lagerkvist, A.; Maurice, C. Evaluation of the critical factors controlling stability of chromium, copper, arsenic and zinc in iron-treated soil. Chemosphere, v.67, p.410-417, 2007. http://dx.doi.org/10.1016/j. chemosphere.2006.08.031

Mallmann, F. J. K.; Santos, D. R. dos; Ceretta, C. A.; Cella, C.; Simunek, J.; Oort, F. V. Modeling field-scale vertical movement of zinc and copper in a pig slurry-amended soil in Brazil. Journal of Hazardous Materials, v.243, p.223-231, 2012. http://dx.doi. org/10.1016/j.jhazmat.2012.10.022

Marcato, S. M. Efeito da restrição alimentar sobre a excreção de minerais nos dejetos produzidos pelos suínos. Pelotas: Universidade Federal de Pelotas, 1997. 67p. Dissertação Mestrado

Mattias, J. L.; Ceretta, C. A.; Nesi, C. N.; Girotto, E.; Trentin, E. E.; Lourenzi, C. R.; Vieira, R. C. B. Copper, zinc and manganese in soils of two watersheds in Santa Catarina with intensive use of pig slurry. Revista Brasileira de Ciência do Solo, v.34, p.1445-1454, 2010. http://dx.doi.org/10.1590/S0100-06832010000400040

Muñoz, J. C. N.; Estévez, M. A.; Novo, C. P.; Periago, J. E. P. Diffusion-induced changes on exchangeable and organic bound copper fractions in acid soil samples enriched with copper. Geoderma, v.148, p.85-90, 2008. http://dx.doi.org/10.1016/j. geoderma.2008.09.009 
Paradelo, R.; Villada, A.; Barral, M. T. Reduction of the shortterm availability of copper, lead and zinc in a contaminated soil amended with municipal solid waste compost. Journal of Hazardous Materials, v.188, p.98-104, 2011. http://dx.doi. org/10.1016/j.jhazmat.2011.01.074

Pires, A. M. M.; Mattiazo, M. E. Cinética de solubilização de metais pesados por ácidos orgânicos em solos tratados com lodo de esgoto. Revista Brasileira de Ciência do Solo, v.31, p.143-151, 2007. http://dx.doi.org/10.1590/S0100-06832007000100015

Plaza, C.; Murias, D. C.; Fernández, J. M.; Polo, A.; Simpson, A. J. Physical, chemical, and biochemical mechanisms of soil organic matter stabilization under conservation tillage systems: A central role for microbes and microbial by-products in $\mathrm{C}$ sequestration. Soil Biology and Biochemistry, v.57, p.124-134, 2013. http:// dx.doi.org/10.1016/j.soilbio.2012.07.026

Rice, E. W.; Baird, R. B.; Eaton, A. D.; Clesceri, L. S. Standard methods for the examination of water and wastewater. 22.ed. Washington: American Public Health Association, part 4000, 2012. 1360p.
Sipos, P.; Nemeth, T.; Kis, V. K.; Mohai, I. Sorption of copper, zinc and lead on soil mineral phases. Chemosphere, v.73, p.461-469, 2008. http://dx.doi.org/10.1016/j.chemosphere.2008.06.046

Souza, R. A. S.; Bissani, C. A.; Tedesco, M. J.; Fontoura, R. C. Extração sequencial de zinco e cobre em solos tratados com lodo de esgoto e compost de lixo. Química Nova, v.32, p.308-314, 2012. http:// dx.doi.org/10.1590/S0100-40422012000200014

Tedesco, M. J.; Volkweiss, S. J.; Bohnen, H.; Gianello, C.; Bissani, C. A. A. Análise de solos, plantas e outros materiais. 2.ed. Porto Alegre: UFRGS, 1995. 212p. Boletim Técnico de Solos, 5

Uprety, D.; Hejcman, M.; Szakova, J.; Kunzova, E.; Tlustos, P. Concentration of trace elements in arable soil after long-term application of organic and inorganic fertilizers. Nutrient Cycling in Agroecosystems, v.85, p.241-252, 2009. http://dx.doi. org/10.1007/s10705-009-9263-x

Ure, A. M. Methods of analysis of heavy metals in soils. In: Alloway, B. J. (ed.). Heavy metals in soils. New York: John Wiley, 1990. p.40-80. 